\title{
The Pivotal Position of the Citizen in The Concept of Territorial Governance
}

\author{
Yassmine ALAOUI and Sidi Mohamed MAMOUN
}

Hassan II University, ENCG, Casablanca, Morocco

Correspondence should be addressed to: Yassmine ALAOUI; Alaouiyasmine1@gmail.com

Received date:24 September 2020; Accepted date: 14 January 2021; Published date: 15 April 2021

Academic Editor: Mohammed Amine Hafiane

Copyright (C) 2021. Yassmine ALAOUI and Sidi Mohamed MAMOUN. Distributed under Creative Commons Attribution 4.0 International CC-BY 4.0

\begin{abstract}
The aim of this research is to examine how local authorities, and more particularly municipalities, should focus on the local population in order to develop their territorial strategies. The study of governance falls within the scope of research on the transformation of local public action and on new forms of multi-level and multi-associates coordination : what roles do the devices and tools, in this case marketing in the fabric of local governance, play for a successful attractiveness, and how can governance be promoted on the basis of an endogenous strategy? The main purpose of this document is to provide a tool enabling deep reflections on better ways to strengthen territorial governance. It sets out the issues involved and proposes to contribute to the engineering of territorial governance defined as "the set of methods and tools enabling the coordination, participation and learning of actors and the piloting of territorial projects".
\end{abstract}

Keywords : Territorial governance, endogenous strategy, territorial attractiveness, citizen.

\section{Introduction}

Territorial governance is neither a myth nor a rhetorical figure, but a tool of intelligence in favor of the shared and harmonious development of the territories. This is the thesis defended in the project PSDR. Gouv. Innov led by roughly twentytwo people, researchers and local actors engaged in the elaboration of a guide, resulting from a joint group, bringing together researchers from various disciplines and a panel of agents of local development of different communities as well as specialized counselors.

The concept of Territorial Governance is folded in meaning, and charged though with two reference switches : the first concerns the governance itself and its modes. The second focuses on the territory itself. These two changes are essential for the survival of a citizen in a territory and for the development of a territory in a world

Cite this Article as : Yassmine ALAOUI and Sidi Mohamed MAMOUN (2021), "The Pivotal Position of the Citizen in The Concept of Territorial Governance", Journal of North African Research in Business, Vol. 2021 (2021), Article ID 342996, DOI : 10.5171/2021.342996 
increasingly marked by complexity and a fierce desire to be part of sustainable social and societal responsibility.

The purpose of this paper is to provide a tool for close reflection to strengthen territorial governance. It sets out involved issues and intends to contribute to the engineering of territorial governance defined as the set of methods and tools enabling the coordination, participation and learning of actors in addition to the management of territorial projects.

\section{Territorial Governance as a Dynamic Process}

In this abridged conceptual construct, territorial governance can be defined as "a dynamic process of coordination (hierarchy, conflicts, consultation) between public and private actors with multiple identities and asymmetrical resources (in the broadest sense: power, relations, knowledge, status, financial capital)"; the emphasis is placed on the need to take into account "the challenges of coordination in asymmetrical situations and on the nature of the dynamic and collective process, which requires learning and favors adaptive approaches bearing on long term outreaches. It cannot be limited to participation, but it also concerns innovative management formulas that make it possible to extend partnerships to public/private combinations, to give priority to integrated and cross-cutting dispositions and to match resources and needs between scales, while strengthening the solidarity of territories around common good practices."

Another comparative analysis conducted by Beuret and Cadoret, covering more than 300 initiatives relating to the conduct of endogenous territorial governance of the environment, reveals organized proximity at adjusted scales, contributing to endow the territories with a specific territorial social capital and setting out the outlines of what could be policies to support these forms of governance.

The interest of such a study for this research topic lies in the fact that the proposed approach can be transposed into fields other than that of the environment.

Indeed, some enlightening notions are, therefore, explained in this analysis: local initiatives led by elected officials, local government officials, associations or ordinary citizens are part of the governance defined as all forms of regulation that are neither market nor State-based (Benko and Lipietz, 1992); a governance that would emerge in the heart of the territories, unlike other forms of governance that would be driven from outside.

Considered here as a way of organizing actors (institutions, companies, associations), this regulation is based more on accommodation than on hierarchy or domination, intended to design and implement a project (Laganier, Villalba and Zuindeau, 2002), within the framework of the creation of an order that results from the interaction of a large number of governors who influence each other (Kooiman and Van Vliet, 1993).

Governance in the territories would then result from two types of dynamics: exogenous territorial governance, established by public authorities outside the territory, in a coercive manner and on the basis of imposed procedures, and endogenous territorial governance from local initiatives. The first would be the result of control regulation, while the second would be more of an autonomous regulation (Reynaud, 1989). Both could be combined in a joint regulation, though.

It is also recalled that many authors such as Leloup (2005), Hüfty (2008) or Létourneau (2009) have emphasized the polysemic character of the concept of Territorial Governance. Let us distinguish the use of "good governance", i.e. transparency and accountability of public management, from governance as a theory that is more concerned with decision-making processes on matters of public interest, referring to a plurality of actors or groups (Létourneau, 2009); It is precisely this second meaning that will be retained here, by focusing on forms of governance that may be independent of public decision-making

Yassmine ALAOUI and Sidi Mohamed MAMOUN, Journal of North African Research in Business, DOI : $10.5171 / 2021.342996$ 
policies but which join them by corresponding to "new ways of producing the common interest" (Petrella and RichezBattesti, 2010).

Quoting Gilly, Leroux and Wallet (2004), who state that "local governance is the process of structuring a compatibility of different coordination modalities between geographically close actors", the authors of this study bring this concept closer to that of local development, also called endogenous, bearing in mind the increasing involvement of private actors in these processes: "processes not only of coordination of the actors, but also of appropriation of the resources and construction of territoriality (...) the virtues of imagination, organization and coordination of these local actors are emphasized" (Leloup et al., 2005).

The place occupied by the state, the market or the multi-partnership coordination allowed Petrella and Richez-Battesti (2010) to distinguish a multilateral or partnership governance that involves a diversity of public and private actors where the public authorities would play the role of a facilitator, of a citizen governance which would be closer to endogenous territorial governance in its function of revealing emerging social demands.

Rich with all these insights, the authors suggest the following definition of endogenous territorial governance as "the set of governance initiatives that emerge in local public spaces and associate actors with various statuses and prerogatives that mobilize around a common good conceived of as a territorial construct." 4

\section{From Consultation to Cooperation}

With Beuret and Cadoret, it is worth recalling that consultation refers to processes of collective construction of visions, objectives and joint projects, with a view to acting or deciding together (Beuret, 2006), where cooperative orientation predominates, the shared intention being to construct together (Touzard, 2006). The endogenous territorial governance is developed in public spaces, in the sense that Habermas understood it in 1978 in his book
Reason and legitimacy, as a place that "rests on the freedom and autonomy of citizens for the training by reason of a collective opinion and will that would influence the production of laws". ${ }^{5}$

Endogenous territorial governance covers a wide range of interventions, depending on whether one is upstream, downstream or at the heart of the dialog between the actors.

The study by Beuret and Cadoret further illuminates a dynamic linkage to the concept of a consultation route that includes several stages: this process begins well with the setting up of forums for consultation, most often aimed at mobilizing or bringing participants closer together, while others may favor the implementation of ideas resulting from consultations or may be at the end of the itinerary.

"Finally, the objective of the initiatives under endogenous territorial governance may be to make a category of actors ready for dialog, to facilitate the emergence of dialog (by offering means of dialog, of rapprochement), to conduct it, to set up mediation in a conflict, to put the ideas resulting from the dialog into action, to consolidate the dialog by enlarging it towards new actors, or to facilitate the reproduction of the dialog in similar situations (dissemination)."

Overcoming the dichotomy between representative democracy (the elected are legitimate to decide on behalf of those who have appointed them) and participatory democracy (citizens and associative representatives are invited to participate in public management), a path would allow the emergence of development spaces cofostered by and for the actors, which would aim less to create a consensus around opinions or proposals (the main objective of the mechanisms of participation), than to build collective action through cooperation.

Therefore, the following definition could be used for collaborative democracy with Beuret and Cadoret (2010): "it is a polycentric democracy which recognizes, as a matter of fact, the distribution of power, resources and information in many hands, and conceives cooperation as one of the

Yassmine ALAOUI and Sidi Mohamed MAMOUN, Journal of North African Research in Business, DOI : $10.5171 / 2021.342996$ 
means of effective coordination. Co-operative democracy aims at building collective action rather than consensus (...) The place of the State of law is rethought with a role of a facilitator, catalyst, and capacitor (...) Finally, it is a democracy called to recognize initiatives taken in favor of an interest that exceeds that of their promoters, based on an attachment to the territory and to certain localized common property."

The concern of the position that endogenous territorial governance would hold in relation to public policies arises here as well; it would seem appropriate to find a place for them in a global space where they would be integrated, where public policies and local initiatives would meet, a space governed by rules laid down by the State and others built by local actors, the action of the government and the on-the-ground experiments in governance.

How then could the existing complementarities be exploited? And what weaknesses and strengths would arise thereby?

\section{From Network to Partnership}

Progressively in the peri-professional literature, the authors of this paper have gone through a semantic shift from the concept of network to that of partnership, highlighting issues relating to the stipulations of cooperation. Of all the definitions, the authors suggest to remember that of Claude Neuschwander, who, in an article in the journal "Pour" in 1991, on the proximity and involvement of the actors vis-à-vis each other, defined the network as "a variable clustering of free actors who maintain strong communication between them." This would have three characteristics:

- First, it would be built around a common interest, an area of knowledge, skills or activities in relation to which the network would establish exchange relations;

- Secondly, this communication would only be maintained if there is understanding (familiar concepts, common features of culture and even shared values);
- Finally, this communication can only be achieved if there is almost immediate mutual credibility; it bears neither deadlines nor procedures; it tolerates neither formalism nor hierarchy; it only concerns individuals, but never institutions.

\section{Considering the Complexity of the Institutional Dynamics Involved: Rules, Meaning and Identity}

Centralization and pyramidal administration have given way to the decentralization and territorialization of actions in the form of programmes which are themselves at the confluence of several public policies. The challenges of the territorial public action that now arise are intrinsically linked to the monitoring of mechanisms boarded by bodies composed of several institutions present in the territory, leading agents of different cultures and professions to work together, with the objective of cross-cutting interventions. It is a question of developing projects which correspond to local problems and users' expectations in order to bring out what Philippe Lyetput forwarded as "Partnership Governance".

Jacques Ion added that the challenge then was "to make asssociates (individuals or institutions) use different languages, have interests that are not convergent and speak the same language". It often emerges that the energy expended in seeking to make collaborations between local and regional authorities, State amenities, associations, etc., is largely as much directed to organizing and regulating collaboration (and consequently the conflicts induced) as to actually carrying out the action.

It is, therefore, not enough to try to enact different policies in a territorial dynamic, to encourage the setting up of a collective decision-making mechanism based on shared and common standards, in order to work together. There is also a need to address intra-institutional and interinstitutional tensions and a real capacity to resist change. In the spirit of what Michel Crozier had pointed out, this resistance was

Yassmine ALAOUI and Sidi Mohamed MAMOUN, Journal of North African Research in Business, DOI : $10.5171 / 2021.342996$ 
due to conflicts of interests, to identities that were sometimes mismanaged or to people's difficulties in finding a meaning in compromises or projects that could have been drawn up without them, leaving them as if they were on the fringes of final decisions.

As Lyet points out, it is regrettable that the extra-institutional dimension of a few actions initiated in an isolated and creative way must face a shortfall in the appropriation of these same actions by the institutions. Indeed, it must be noted that "there is a general discrepancy between this development of initiatives (by bottom-up creation or by top-down appropriation) and the weak capacity of organizations, on the one hand, to accompany their professionals in their endeavors to create a project ex nihilo (...) and, on the other hand, to allow local "inventions" to be disseminated to other agents and services of the organization for enlightening and enriching by the accumulation of experiences of other similar initiatives."

It also warns us against the risk of a strategy of reorientation of the public action that could be made dysfunctional by institutional shortage: indeed, it might be thought that the renewal of an action entrusted in a shared project mode to several actors in a capacity to act, and based on characteristics that are cross-cutting and known to them, would be sufficient to escape from too rigid and uniform modes of intervention; but this is not the case: indeed, several objections could be raised.

First, this strategy for the development of public action would be akin to a management approach that would emphasize the initiative capacity of small project-carrying collectives and the empowerment of a few actors, who themselves are reduced to an individual dimension (Boltanski and Chiapello, 1999). But it seems hazardous to separate, on the one hand, the issue of action and its development and the issue of power on the other. However, this is what most of the recent public policy strategy is about: the control and carrying of the actions that remain disconnected.
Second, there is a risk that the price of this strategy will be too high. Indeed, it is sometimes the case where a lot of effort is exerted on an uncertain result, which is not always profitable and which could fade out once the collective disbands.

Thirdly, an action is not merely an adaptation to a need; its construction process is an institutional creation anchored in a certain layout of problems and solutions. Besides, what is invented in a partnership if it cannot be transposed as it is - always carries lessons for others because it allows building a normative or symbolic framework, likely to spawn new developments, jointly between local and global, elsewhere for instance.

"In brief, for the question we are interested in, these territorial and transversal collaborations, faced with the evolution of the issues, mobilize professionals to look for new modalities of action, in collaboration with stakeholders with whom they were not used to working with. The aim is to achieve what Pierre Tesseirenc (1994) called "institutional creation" in relation to local development initiatives. However, this process is rarely successful for reasons that lead to the question whether these new forms of public action might not be institutionally deficient."

Everything seems to show that partnership governance is experienced in a paradoxical way. If the various associates of a territory, mobilized on a co-construction action, acknowledge their interest and openly value it, their commitment and "real" involvement in this partnership will also tend to be anxious sometimes, putting them in a situation where they would be led to abdicate part of their "power" in a collective game with uncertain contours.

It is clear that new perspectives are emerging on the very commitment of the associates; Berthoin Antal and Sobczak's article spells out on different approaches: indeed, the evolution of societal issues leads local actors to hold different expectations towards companies, in particular. It is no longer just a question of evaluating the achieved performance, but the focus is on

Yassmine ALAOUI and Sidi Mohamed MAMOUN, Journal of North African Research in Business, DOI : $10.5171 / 2021.342996$ 
broader societal issues that often require complex solutions, such as combating global warming, promoting equal opportunities...etc.

"By moving from the term Business-Society Relations to the term Corporate Social Responsibility, the perspective of analysis is changed, putting the company, its activities and its decision-making methods at the heart of the debate. This has also been reflected in the theoretical frameworks mobilized by management scientists (Gond and Mullenbach-Servayre, 2003) Associates Theory, Contractualist Theory and Institutionalist Theory - all revolve around different ways of conceiving the role of the company and its relations with other actors." 12

This was particularly relevant when $\mathrm{R}$. Edward Freeman, in 1984, developed the Associates Theory by focusing his analysis on the relationship between business and society and even more on corporate social responsibility; that theory was then taken over by researchers like Post, Preston and Sachs in 2002, to define the principles allowing companies to "manage" their associates in an instrumental perspective. In an increasingly complex global context, the issue of economic, social and environmental issues increasingly involves the co-construction of collective solutions with all actors, regardless of their statuses. Bento, 2009, then suggested moving towards the broader notion of social responsibility of organizations (not only companies). In the same vein, Berthoin Antal and Sobczak, 2004, propose to go even further to retain the notion of global responsibility, which also better emphasizes that the interests to be taken into account are not only social, but also environmental and economic, and that they must be addressed in a transversal and international context.

\section{Endogenous Governance and New Territorial Marketing}

The approach of territorial marketing, and thus, the project of territorial attractiveness must be communicated first to the inhabitants, and possibly co-produced and made for and by the residents; not only shared, but also understood and held by the associates, hence, the importance of the application of a strategy of governance that begins with the resident and that emerges from the heart of the territory, can in no way be influenced from outside.

In this sense, it is important to focus on the citizen's involvement, which constitutes the basic component of the approach of hospitality defined as the capacity of a territory to keep on site the resources (residents, tourists and investors) already retained.

Local involvement is no longer a choice, but a primary necessity for the success of the approach of territorial attractiveness, for two main reasons: the first is to involve the citizen directly in the management of the public case, as the territory project should reflect his persons in general. The second confirms the number of voices that have recently been raised in order to advocate the search for the intangible assets of the territories consisting in addressing first the sensitivity, the affection and the sense of belonging of the resident. It is this resident who builds and constitutes the territory on a daily basis and who, in fact, cooperates in conveying what makes the territory what it is from his own perception, and thus directly or indirectly shapes his brand image.

In the same vein, it is important to remember that the resident can play four roles in relation to his territory: he is a direct target on board, he can be an argumentator valuing the territory, a partner in building the appeal process and finally an ambassador and a passionate lawyer who can easily influence the decision of other targets.

\section{Conclusion}

The notion of governance and/or Associates Management has evolved into that of Engagement, reflecting the fact that a few innovative companies have moved from the reactive management of societal issues, which was limited to meeting standards, to the implementation of more proactive and interactive initiatives that allow these issues 
to be addressed more effectively through engagement strategies of their associate networks (Andriof \& Waddock, 2002).

The very notion of commitment needs be clarified: in Anglo-Saxon culture, this term evokes a marriage or an agreement and a struggle as well; in the French dictionary, this idea is fairly well located in "a shortterm and localized struggle", as in "taking sides on political and social problems through one's actions and speeches".

It is worth recalling here that Greenwood (2007) proposed defining associates' engagement as a process or processes for consultation, communication, dialog and exchange. The authors also propose, together with Berthoin Antal and Sobczak, to define the involvement of associates "as the active creation of learning relationships with the various associates in order to find solutions to economic, social and environmental challenges", bearing in mind that conflict may seem almost inevitable.

This illustrates the diversity and complexity of forms of governance marked by associates' engagement, with different approaches cited in this article revealing a human dimension inherent in any engagement, giving an appearance to each associate; the energy of the conflict having to be transcended to upgrade to a more constructive relationship based on compromises grounded on innovative solutions. Other approaches emphasize the emotional dimension of endogenous governance and associates' engagement in global responsibility that often rests on the passion of individuals, their empathy and their ability to influence or train others. This portion of subjectivity should not be underestimated.

\section{References}

- $\quad$ Barbe E., Rey-Valette H., Chia E., Clément C., Durif H., Guiheneuf P.Y., Jarrige F., Laurent A., Maurel P., Michel L., Paillhès A., Pinto M., Soulard CT., Gouvernance des territoires et développement durable : une analyse des innovations organisationnelles, PSDR GOUVINNOV Project, Pour et Sur le Développement
Régional, Languedoc-Roussillon, Série Les 4 pages PSDR3, 2011

- Bertacchini, Y. (2002). Territorial concertation and concerted territorial policy. International Journal of Info \& Com Sciences for Decision Making, (5), 1-6. Retrieved from http://archivesic.ccsd.cnrs.fr/sic_0000 0477

- Beuret, J. E., \& Cadoret, A. (2011). Endogenous territorial governance of the environment: Contours and issues: Nearly 300 initiatives submitted to a comparative analysis. Geographie Economie Societe, 13(4), 363-386. http://doi.org/10.3166/ges.13.363386

- Bourdeau-Lepage, L., Huriot, J.-M., \& Perreur, J. (2009). À La Recherche De La Centralité Perdue. Revue d'Économie Régionale \& Urbaine, July (3), 549. http://doi.org/10.3917/reru.093.0549

- Bourret, C. (2008). Elements For An Approach To Territorial Intelligence As A Synergy Of Local Projects To Develop A Collective Identity. Projectics / Proyéctica / Projectique, 0(1), 79. http://doi.org/10.3917/proj.000.0079

- Burgos-Vigna, D. (2010). Participatory democracy and city attractiveness in Latin America. Mondes En Développement, $\quad$ 149(1), 53. http://doi.org/10.3917/med.149.0053

- Chamard, C. (2014). Territorial marketing. How to develop the attractiveness and hospitality of territories. De boeck.

- Desjardins, X. (2014). Reform through change of scale: a look back at a disappointed ambition of intermunicipal cooperation. Geography, Economy, Society, 16(3), 275-296. http://doi.org/10.3166/ges.16.275296

- Dumont, M. (2004). Microterritories in urban planning, paradoxical spatial and social objects. Revue.org, Norois, 193.

- $\quad$ Eshuis, J., Klijn, E.-H., \& Braun, E. (2014). Territorial marketing and citizen participation: branding as a way to cope with the emotional dimension of policymaking? Revue Internationale Des Sciences Administratives, 80(1), 153.

http://doi.org/10.3917/risa.801.0153 
- Fauchard, L., Mocellin, P. (2009). Conduire une démarche de prospective territoriale. L'harmattan.

- Friboulet, J.-J. (2010). La construction de l'attractivité : une analyse en termes de capacité. Mondes En Développement, 149(1), 11. http://doi.org/10.3917/med.149.0011

- Gérardin, H., \& Poirot, J. (2010). The attractiveness of territories: a multidimensional concept. Mondes En Développement, 149(1), 27. http://doi.org/10.3917/med.149.0027

- Gollain, V. (2014). Succeeding in your territorial marketing approach. Method, techniques and best practices. Dossier d'expert. Territorial éditions.

- Guesnier, B., \& Lemaignan, C. (2004). The emergence of creative territories. Revue d'Économie Régionale \& Urbaine, February(1), 135. http://doi.org/10.3917/reru.041.0135

- $\quad$ Halter, J.-P., Lorrot, P., \& Weiss, D. (2004). Psychosociology and the government of "Territories". International Journal of Psychosociology, X(1), 122. http://doi.org/10.3917/rips.022.0122

- Heckscher, C., Qu, O., Souhaitent, E., \& Ensemble, A. (2015). "There is another kind of negotiation: when parties try to collectively envision a goal they want to achieve together." http://doi.org/10.3917/neg.023.0023

- Leloup, F., Moyart, L., \& Pecqueur, B. (2005). Territorial governance as a new mode of territorial coordination? Geographie Economie Societe, 7(4), 321-331.

http://doi.org/10.3166/ges.7.321-331

- Leroux, I. (2006). Territorial governance and bargaining games. Négociations, 6(2), 83. http://doi.org/10.3917/neg.006.98

- $\quad$ Lucet, A., Rouzet, C., Vivien, B. (2015). Management by project. Tools for territorial reform and communities. Dossier d'experts. Territorial éditions.
- $\quad$ Lyet, P. (2008). The uncertain institution of partnership. A socio-anthropological analysis of partnership governance in territorial social action. L'harmattan.

- $\quad$ Maurel, P., Barbe, É., Rey-valette, H., Chia, E., Soulard, C., \& Pinto, M. (2014). Feedback on the co-construction of a guide on territorial governance.

- Pelissier, M. (2009). Étude Sur L ' Origine Et Les Fondements De L ' Intelligence Territoriale : L ' Intelligence Territoriale Comme Une Simple Déclinaison De L ' Intelligence Économique À L ' Échelle Du Territoire? International Review of Economic Intelligence, 1, 291-304

- $\quad$ Pinson, G. (2010). La gouvernance des villes françaises. Métropoles, (7). Retrieved from http://metropoles.revues.org/4276

- Requier-Desjardins, D. (2009) Territoires - Identités - Patrimoine : une approche économique ? in Développement durable et territoires, dossier $\mathrm{N}^{\circ} 12$, p.16

- $\quad$ Rey-Valette, H., \& Mathé, S. (2012). The evaluation of territorial governance. Issues and methodological proposals. Revue d'Économie Régionale \& Urbaine - RERU, (2012/5), 783-804. http://doi.org/10.3917/reru.125.0783.

- $\quad$ Sigot, F., Les territoires se mettent en quatre pour booster leur attractivité, La Gazette, March 2016, p. 46-47

- Sobczak, A., \& Antal, B. (2010). NEW PERSPECTIVES ON STAKEHOLDER ENGAGEMENT: ISSUES, ACTORS, RESEARCH Dossier New perspectives on stakeholder engagement: issues, actors, research coordinated by André Sobczak and Ariane Berthoin Antal Co.

- Villemus, P. (2014). Magic Marketing. Reinventing growth. Dunod. Translated with www.DeepL.com/Translator (free version) 